\title{
Kuri silm: toimemehhanismid lähtuvalt antiiksetest ja keskaegsetest tajuteooriatest $^{1}$
}

\begin{abstract}
Meelis Friedenthal
Teesid: Artikli eesmärgiks on esitada põhjalikumalt erinevate nägemisteooriate taustal kurja silma fenomeni kirjeldus, toetudes nii antiiksetele kui ka keskaegsetele nägemisteoreetikutele. Eesmärgiks on näidata, et kuri silm kuulus loomulikuna omaaegsesse teaduslikku maailmapilti ning oli igati kooskõlas toonaste filosoofiliste arusaamadega, baseerudes mitte ainult nägemisteoorial, vaid arusaamadel epistemoloogiast ja ontoloogiast üldiselt.
\end{abstract}

Märksõnad: ekstramissioon, intromissioon, hülomorfism, kuri silm, nägemisteooriad

Kuri silm ehk fastsinatsioon ${ }^{2}$ kui nähtus on juba antiigist tuttav fenomen ning see on huvi pakkunud uurijatele nii keskajal kui ka tänapäeval (Elworthy 2004; Seligmann 1922; Dundes 1992). Enamasti on pööratud tähelepanu eelkõige kurja silma üksikjuhtumitele ja selle nähtuse avaldumisvormidele, samuti on tähelepanu pälvinud kurja silma kandjad ja nende positsioon ühiskonnas. Niisugusele pigem kirjelduslikule tendentsile viitab ka Alan Dundes, kellelt pärineb üks viimaseid põhjalikumaid teaduslikke uurimusi kurja silma fenomeni kohta. Ta mainib oma kokkuvõtlikus artiklis, et "arutelu kurja silma üle seisneb valdavalt erinevate juhtumite pajatuslikus edasiandmises" (Dundes 1992: 262). Teisisõnu on meil palju folkloorset materjali kurja silma kohta, aga küsimus sellest, millise mehhanismi abil kuri silm tegutseb, on jäänud pigem marginaalseks. Selle nähtuse seletamiseks ei ole esile kerkinud ühtegi hõlmavat teooriat, kuigi võimalike variantidena on pakutud välja nii vaime kui ka deemoneid (Story 2003: 162-163), aurusid (miasme) (Stearns 2011: 92-105), kadedust, võimusuhteid, humoraalseid teooriaid jpt (Dundes 1992: 262-267, 50-51, passim). Mainitud on sealjuures sageli nägemise ekstramissiooniteooriat, kui sellise arusaama võimaldajat, kuid enamasti peatutakse nägemisteoorial lühidalt ja üldsõnaliselt. ${ }^{3}$ 


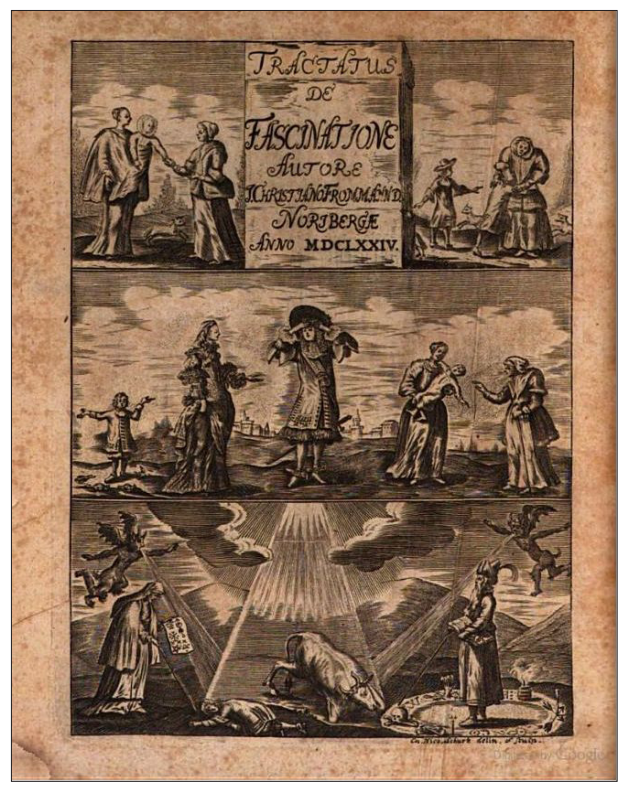

Joonis 1. Johann Christian Frommanni Tractatus de fascinatione novus et singularis näitab vaselõikel fastsinatsiooni kolme võimalikku seletust. Esiteks tajuorganite kaudu (puudutus, kõne, pilk); teiseks aurude (effluvia) kaudu; kolmandaks deemonite abil. See raamat on olemas ka Tartu ülikooli raamatukogus, kahjuks aga ilma vaselõiketa, mille keegi on raamatust eemaldanud.

Käesolev artikkel püüab esitada põhjalikumalt erinevate nägemisteooriate taustal kurja silma fenomeni kirjelduse, toetudes nii antiiksetele kui ka keskaegsetele nägemisteoreetikutele. Eesmärgiks on näidata, et kuri silm kuulus loomulikuna omaaegsesse teaduslikku maailmapilti ning oli igati kooskõlas toonaste filosoofiliste arusaamadega, baseerudes mitte ainult nägemisteoorial, vaid arusaamadel epistemoloogiast ja ontoloogiast üldiselt. Kuigi autorite nägemisteooriad on küll detailides mõnevõrra erinevad, on selgesti jälgitav teatav ühtne arusaamine nägemise ja hinge omavahelisest seosest. Kindlasti on tähtsal kohal ka nägemise ja valguse olulisus antiigis ja kristlikus mõtlemises (Jay 1993).

\section{Ekstramissioon}

Püüdel omaaegse teadusega kurja silma seletada on pikad traditsioonid (Dickie 1991). Ühena esimestest esitas põhjalikuma käsitluse kurja silma kohta esimese sajandi kirjanik Plutarchos oma Lauakõnedes, toetudes talle tuntud autorite (eelkõige Demokritos, Pseudo-Aristoteles) (Dickie 1991: 25) teooria- 
tele. Muuhulgas mainis ta peatükis "Nende kohta, kellest öeldakse, et nad kaetavad" järgmist:

Sest nägemine, mis on väga liikuv ja aktiivne, saadab koos vaimuga, millest ta sõltub, välja kummalist tulist jõudu; nii et sellepärast hakkavad inimesed tegutsema ja kannatavad väga, ja on alati vastavalt rahul või pahased, nõnda nagu nähtavad objektid on neile meeldivad või mitte. [...] Niisiis, kui kadeduse poolt väärastunud hingega inimesed vaatavad oma silmaga kedagi teist, ja need [silmad], kuna on hingele kõige lähemal, tõmbavad sealt kergesti välja mürki ja saadavad seda välja nagu mürgitatud nooli. (Plutarchos, Quaestiones Convivales, 681a jj)

Sellest lõigust ilmneb selgelt Plutarchose seisukoht, et igasugune silm - olgu kuri või mitte - saadab endast välja "kummalist tulist jõudu", mis on kuidagimoodi hingega ühendatud. Kurja silma omanikud näivad olevat erilised vaid selle poolest, et nende hinges on midagi kurja, mis silmade kaudu teiste inimesteni kandub. Plutrachos toob siin välja kadeduse, mis aga on vaid üks võimalus - niiviisi võivad üle kanduda igasugused vaataja hingeseisundid, mis ei pea tingimata olema isegi negatiivsed. Just selle pärast ütleb Plutarchos, et inimesed on "vastavalt rahul või pahased".

Hilisemas kirjanduses hakatakse arusaama, et millegi nägemiseks saadetakse silmast välja kiired, nimetama ekstramissiooniliseks või emissiooniliseks nägemisteooriaks ning vastandatakse seda intromissioonilisele, ehk siis teooriale, mis saab nägemisest aru viisil, et väljast saadetakse midagi silma sisse. Ekstramissiooniline arusaam, mida Plutarchos kurja silma kontekstis kirjeldas, baseerub esiteks Demokritose arutlusel, mis on väga tugevalt mõjutanud kõiki järgmisi nägemisteooriaid. Võib öelda, et selline lähenemine oli antiigis kõige levinum - emissioonilist positsiooni toetasid nii platoonikud kui ka pneumaatikud (nagu nt Galenos, kes hilisematel sajanditel sai väga mõjukaks). Ka Eukleidese, Heroni ja Ptolemaiose ${ }^{4}$ võib nende töödes leiduvate mõningate vihjete tõttu paigutada samasse rühma. Nende matemaatiline nägemisteooria ei kätkenud endas siiski psühholoogilist elementi ning tundis huvi nägemise vastu pigem geomeetriast lähtuvalt. (Lindberg 1976: 11-17.)

Demokritose teooria on varaseim veidigi põhjalikumalt välja töötatud nägemisteooria ning see seletab, et nägemiseks lähtub silmast liikumine, mis pressib õhu silma ja nähtava objekti vahel kokku, millele tekib seejärel kujutis, mis kandub omakorda edasi inimese hinge (Taylor 2010: 108). Tuliseks saab seda liikumist nimetada (nagu seda teeb ka Plutarchos) põhjusel, et hing ja tuli on olemuselt sarnased. Silmast lähtuv liikumine on samalaadne inimese hinges toimuva liikumisega. Ka Platon võttis suuresti selle arusaama üle ja arendas omalt poolt edasi. Nimelt rääkis ta dialoogis Timaios (45b) võrdlemisi 
lühidalt ja möödaminnes, et silmas on tuli, mis moodustab sealt väljudes väljas oleva valgusega "homogeense keha" ja see keha, saades vaadeldavast objektist lähtuva tulega igatpidi omaduste poolest sarnaseks, kannab teadmise nende kohta edasi inimese hinge. Platoni tekstist ilmneb ka, et nägemiseks on kindlasti vaja välist valgust, sest silma sees olev tuli ei ole piisavalt võimas selleks, et omal jõul pimedusest läbi tungida. Seega muutubki pimeduses nägemine jõuetuks, et ei leia enam midagi sarnast (st valgust) ja selle tagajärjel kustub sarnane toimib koos sarnasega. Platoni arusaam toetus siinjuures arvatavasti ka Empedoklese seisukohtadele nägemisest (Empedoklese teooria on meieni jõudnud siiski nii fragmentaarselt, et kõiki tema seisukohti ei ole võimalik täpselt kindlaks teha). (Long 1966: 263-264.)

Antiigi emissioonilised nägemisteooriad võeti hiljem üle nii kristlikus Euroopas kui ka moslemite juures. Varakeskajal sai Euroopas valitsevaks suuresti just platonistlik traditsioon, kuna Platoni nägemist puudutav osa dialoogist Timaios oli üks vähestest kreekakeelsetest filosoofilistest tekstidest, mis olid ladina keelde tõlgitud. Antiikajal eeldati, et teaduste ja meditsiiniga tegelejad on loomulikult kursis kreeka keelega, kuid alates 7. sajandist hääbus Euroopas aegamööda kreeka keele oskus. Selle tagajärjel jäid kreeka filosoofia allikateks sajanditeks peamiselt ladina autorite entsüklopeediatesse ja kogumikesse koondatud nopped ja lühikesed tõlked, mille tagajärjel oli nt Aristotelese nägemisteooria keskaja varasel perioodil peaaegu tundmatu. Hoolimata sellest hakkasid valgus ja nägemine mängima kristlikus teoloogias olulist rolli, toetudes Augustinuse ja Ps. Dionysius Areopagita teostes leiduvatele tähelepanekutele valguse metafüüsikast, kus inimsoo au ja hiilgust (saavutusi) nähakse jumaliku hiilguse varjuna. Platoni koopaanaloogia ja Plotinose Enneaadide vaimse traditsiooniga seotud ettekujutus arenes 13. sajandi alguses Robert Grosseteste'i kirjutistes värskelt tõlgitud Aristotelese teoste mõjul universaalteaduse loomise poole, kus valguse metafüüsikal oli keskne positsioon. Just sellesse perioodi on paigutatud ka valguse ja nägemise muutumine Lääne mõtlemise keskseteks metafoorideks (Jay 1993: 38-41), mille üheks peamiseks allikaks on muidugi Gen 1,3 - fiat lux. Selliselt on mõistatav ka antiiksete kurja silma puudutavate uskumuste ja seletuste ülekandumine keskaegsesse Euroopasse ning nägemist ja valgust puudutavate metafooride küllus teoloogilises ja filosoofilises mõtlemises.

\section{Intromissioon}

13. sajandil toimus Euroopa mõtlemises muutus ning eelnevalt eelistatud platonistlik nägemisteooria asendus aegamisi intromissioonilise nägemisteooriaga, mis toetus esiteks Aristotelese arusaamadele, aga ka tema teooriaid edasi 
arendanud moslemi filosoofide kirjutistele. Ometigi ei kadunud ka selle tagajärjel uskumused kurjast silmast ning on võimalik näidata, et ka intromissiooniline nägemisteooria võimaldas kurja silma fenomeni teaduslikult seletada. Lühidalt - kurja silma toimimiseks ei ole ekstramissiooniline nägemisteooria olemuslikult vajalik.

Keskaja kõige olulisemaks nägemise ja perspektiivi teadusesse puutuvaks tööks kujunes 13. sajandi algupoolel ladina keelde tõlgitud Alhaceni ${ }^{5}$ (Ibn alHaytham, ca 965-1039) De aspectibus, mis on sel ajal tõlgitud optikaalastest tekstidest üks hilisemaid, aga selle eest võibolla kõige suurema mõjujõu ja autoriteediga. Alhacen kombineeris omavahel Aristotelese ja atomistide teooriad nägemise kohta, matematiseeris need ning toetas oma argumentatsiooni mitmete mõtte ja ka praktiliste eksperimentidega, mis saaid intromissiooniteooria valitsevaks muutumisel otsustavaks. Tema pakutud seisukohad nägemise toimimisest võeti entusiastlikult üle Lääne filosoofide poolt (nt Roger Bacon ja Witelo) ja need jäid tooniandvaks 17. sajandi alguseni, mil ilmus Johannes Kepleri (1571-1630) uutele vaatlustele ja uuenenud teadmistele silma anatoomiast põhinev Ad Vitellionem paralipomena. Etteruttavalt võib öelda, et just varauusajal hakkasid esile kerkima ka kurja silma toimimise uued teooriad, mis ei toetunud enam niivõrd nägemisele, kuivõrd just aurudele ja deemonite tegevusele (Story 2003: 162). Teisisõnu said eelnevad loomulikel või tavalistel looduse protsessidel põhinevad kurja silma teooriad varauusajal üleloomuliku põhjenduse. ${ }^{6}$

Aristotelese nägemisteooria (mis on intromissiooniliste teooriate peamiseks aluseks) oli palju põhjalikumalt välja töötatud kui Empedoklesel, Demokritosel või Platonil. Aristoteles tõi välja ka eelmiste filosoofide seisukohti ning kritiseeris neid teravalt. Tema enda nägemisteooria aluseks oli eeldus, et valgus levib läbipaistvas keskkonnas (õhus, vees, teatud ainetes) silmapilkselt, see tähendab, et tegelikult ei saa üldse rääkida mingisugusest liikumisest, vaid olukord läbipaistvas meediumis lihtsalt muutub. Tajuaktis ei ole seega mingit rolli objektidest lähtuvatel aatomitel (nagu mõned atomistid seda kirjeldasid ja hiljem ka 17. sajandi teoreetikud seda hakkasid mõistma) ega ka silmast lähtuval tulel. Aristoteles ise võttis need mõisted kokku:

Mis on läbipaistev ja mis on valgus, on seega öeldud, st see ei ole tuli ega keha üldiselt ega ka mitte lenduv kehalt (sest sel juhul oleks see ikkagi keha), vaid tule või millegi sarnase kohalolek läbipaistvas keskkonnas (Aristoteles, De anima, 418b13).

Nägemine saab teoks põhjusel, et silm koosneb veest ning sellisena osaleb ta läbipaistvas meediumis. Kui seal toimuvad mingisugused muutused, saab silm nendest automaatselt (aga passiivselt) osa. Seetõttu Aristotelese arusaama 
käsitlemine intromissioonina, kus silma saadetakse väliskeskkonnast midagi sisse ja silm tegutseb vastuvõtjana, on küll võimalik, aga siiski selle teooria lihtsustatud kirjeldus. Olulisem on ikkagi läbipaistva keskkonna olemasolu, kus silma ja objekti vahel tekib aktuaalne ühendus. Võib isegi väita, et Aristotelese intromissiooniline ja Platoni ekstramissiooniline nägemisteooria ei olegi nii vastandlikud, vaid pööravad eelkõige tähelepanu ühenduse või silla loomisele välise objekti ja vaatleja vahel. (Lindberg 1976: 9.) Silmast lähtuva või silma tuleva valguse vms liikumise suund ei ole seega määrava tähendusega. Just selle kaudu saab ka mõistetavaks kurja silma toimimine - igasuguse nägemisaktiga luuakse kontakt vaadatava asja ja inimese vahel ning kellegagi pilgu ristamine loob ühenduse selle inimesega ja tema hinge omadustega. Need aga võivad kontakti abil üle kanduda ja kahju tekitada.

Selliselt kirjeldatud arusaam jätab aga ebaselgeks küsimuse, mille abil objekti või inimese omadused meieni jõuavad ehk kuidas saab kuri silm ümbritsevat aktiivselt mõjutada. Plutarchos (ülaltoodud näites) räägib siinkohal mingisugustest "mürgitatud nooltest" ja Platon sellest, et nägemine muutub pimeduses jõuetuks - seega on nägemises mingisugust sorti jõud ja ta kannab edasi mingisugust teavet vaataja kohta. Järgnevalt tuleb leida vastus küsimusele, et kui luuakse ühendus vaatleja ja objekti vahel, siis mis moodustab ühendust loova jõu ning mis on need "nooled", mis võivad kurja silma abil üle kanduda.

\section{Fantasmid ja kujutised, mis on tegutsevad ja mõistusel}

Plutarchos laseb juba eelmainitud lauakõne lõpus märkida ühel vestlejal järgmist:

[Demokritos] väidab, et kadedad saadavad välja pilte, mis ei ole täiesti lagedad sisust ja jõust, vaid täis häirivaid ja mürgiseid omadusi, mis pärinevad nendelt, kelle juurest nad tulevad (Plutarchos, Quaestiones Convivales, 682f-683a).

Paraku ei arenda Plutarchos seda mõttekäiku pikemalt edasi ning õhtune lauakõne jääb Demokritose teooria üle arutades pooleli, et nii hilisel tunnil mitte "tuua sisse fantasme ja kujutisi, mis on tegutsevad ja mõistusel" (Plutarchos, Quaestiones Convivales, 683b). Vestlejad lepivad küll omavahel kokku, et hommikul nad jätkavad samal teemal, millest aga lauakõnedes kahjuks enam ei kirjutata. Ometigi võib siit leida olulisi viiteid kurja silma toimimise mõistmiseks. Tehnilist terminit, mida Plutarchos siinses kontekstis kasutab eidolon ( $\varepsilon \hat{\imath} \delta \omega \lambda \circ \nu)$ - on tõepoolest võimalik tõlkida pildiks või kujutiseks, kuid 
juba varakult oli selle sõna tüvi laiema tähendusväljaga kui üksnes kujutis. (Liddell 2000.) Demokritos ja hilisemad atomistid olid seisukohal, et meieni jõuavad mingisugused väikestest materiaalsetest osakestest koosnevad pildid, mida kõik kehad igas suunas välja kiirgavad ja mis füüsiliselt kannavad edasi oma kujutise silmale ja teistele meeleorganitele. ${ }^{7}$ Silmast lähtuva liikumise teooria on Demokritos võtnud kasutusele arvatavasti seepärast, et muidu ei oleks võimalik selgitada, kuidas me saame näha nii suuri asju nagu mäed jms. Niisiis liiguvad kõigist objektidest kogu aeg välja kujutised, mis on täpselt nende suurused ja samade omadustega ning silmast lähtuv liikumine kohtub nendega nn poolel teel. Üks hiliseid atomiste Lucretius kirjeldab neid sellisel viisil:

Esiteks, paljud objektid saadavad ilmselgelt esile kehasid, mõned neist tükati ja segatult nagu suits puudest ja kuumus tulest, aga mõned rohkem läbipõimunult ja kokkusurutult, nagu siis, kui rohutirtsud suveajal panevad kõrvale oma läikivad tuunikad, või kui vasikad sündides lasevad langeda kilel oma keha pinnalt või jällegi nagu libe madu ajab oma rõivad maha okaspõõsaste vahele. (Lucretius, De rerum natura, IV.54-61)

Sedasi justkui kompides neid kujutisi pöördub hinge liikumine tagasi inimesse ja annab meile teavet nähtu kohta. Kirjeldatud viisil ei toimu mitte ainult nägemine vaid kõik meeletajud tegutsevad põhimõtteliselt sarnaselt.

Seega ei saa me atomistide teooria järgi välisilmast mingisugust muud infot, kui vaid seda, mida kehadelt lenduvad osakesed oma liikumise kaudu meieni kannavad. (Taylor 2010: 119.) Nii näiteks saame punasest värvist aistinguid osakeste abil, mis on sama sorti kui kuumadelt asjadelt saabunud osakesed, seetõttu ühendame ka punase värvi kuumaga. Kuna Demokritosel on ka hing (ehk mõistus) materiaalne liikumine keha sees, võib järeldada, et teatud määral jõuab ka see igasuguse tajuakti kaudu tajuja juurde ning kannab osa enda omadustest üle tajujale. Plutachose järgi võib mõista, et eelkõige toimub see silmade kaudu, millel on kõige otsesem ühendus hingega - silmi on küll võimalik näha nagu kõiki teisi objekte, kuid samas on nad avaus, mille kaudu lenduvad välja ka silmade omaniku hinge ja mõistuse osakesed. Ristates kellegagi pilgu jõuab meieni teataval määral selle inimese hing, ning kuna see hing on liikumine, võib see mõjutada omakorda meie hinge sisemist liikumist. Sellist arusaama toetab ka tähelepanek, et jumalad on Demokritosel teatavat sorti eidola, mis ilmuvad inimestele unedes ja millega on võimalik suhelda. (Taylor 2010: 215.) Just neid aspekte võis Plutarchos silmas pidada, kui mainis, et ei soovinud vestlusesse sisse tuua "kujutisi, mis on tegutsevad ja mõistusel". Samas on ilmne, et ta suhtub atomistide teooriasse mõningase kõhklusega.

Aristoteles ja tema järgijad peavad sellist atomistide kirjeldatud füüsilist omaduste edasikandumist otsesõnu suureks mõttetuseks (Taylor 2010: 119). 
Teoses De sensu (442a29-b24), kritiseerib Aristoteles Demokritose teooriaid taju kohta ning jõuab järeldusele, et selline füüsiline info ülekandumine ei saa teostuda. Otsustavaks peab ta argumenti, et niiviisi muudatakse kogu taju teatud määral kompimise sarnaseks ja objektide üldiseid omadusi nagu kuju ja suurus käsitletakse vaid teatud meele spetsiifilisena (Taylor 2010: 119). Aristotelese enda arusaam tajust ei sisalda kujutiste materiaalset ülekandumist vaid osasaamist läbipaistvas meediumis toimunud muutustest. Eelkõige baseerub tema niisugune arusaam teoorial hingest. Oma hinge käsitlevas teoses toob Aristoteles välja, et hing on keha vorm (eidos). Sõnatüvi on siin sama, mis Demokritose "tegutsevate ja mõistusel" olevate "kujutiste" puhul. Niiviisi Aristotelese poolt mõistetud hinge ei saa aga mingil juhul käsitleda materiaalsena (aatomitest ja elementidest koosnevana) ega ka välise paistusena, vaid see tähistab pigem olemust.

Sest kui silm oleks loom, siis oleks nägemine tema hing, sest see on silma olemus ja vastab tema printsiibile (logos). Silm on nägemise materjal ja kui see ära kaob, ei ole ta enam silm, vaid on seda ainult nime poolest, nagu silm kivis või maalitud silm. Me peame nü̈̈d rakendama kogu elavale kehale seda, mis kehtib osa kohta, sest nii nagu osa [tajust] suhtub [keha] osasse nii on taju (aisthesis) tervikuna kogu tajuvale kehale. (Aristoteles, De anima, 412b17-25.)

See printsiip või hing on ka viis, mille abil me väljaspool olevaid objekte tajume:

Üldiselt, mis puutub igasugusesse tajusse, peab mõistma, et taju on on see, mis võtab vastu tajutavaid vorme (eidon) ilma mateeriata, nagu näiteks vaha võtab vastu pitsersõrmuse märgi ilma raua ja kullata - ta võtab vastu kuldse või pronksise märgi, aga mitte kui kui kulla või kui pronksi; ja tõepoolest sarnaselt taju iga asja suhtes võtab vastu selle, millel on värv või maitse või heli. (Aristoteles, De anima, 424a17-24.)

Niiviisi mõistetud taju ja hing ei piirdu aga ainult väliste omaduste edasikandumise ja vastuvõtmisega tajuaktis, vaid on palju laiem (Gregoric 2007: 33-43). Oluline on siinkohal asjaolu, et:

See, mis suudab tajuda, on, nagu eelnevalt ütlesime, potentsiaalselt selline nagu taju objekt on aktuaalselt. Ta ei ole selline nagu objekt, kui talle mõjutakse, kuid ta saab selle sarnaseks, kui teda on mõjutatud ja on nii nagu see mõjutaja on. (Aristoteles, De anima, 418a3-6.)

Seda võib käsitletava teema kontekstis lühidalt niimoodi tõlgendada, et teatud määral kantakse iga vaadeldava objekti omadused üle inimese hinge. Protsessi mehhanism on küll oluliselt erinev atomistide füüsilisest ülekandumisest, aga võimaldab siiski samamoodi muutusi vaataja hinges. Sellist muutuste püsimist ja ülekandumist iseloomustab Aristoteles ise näitega (Sprague 1985: 323-325): 
Et tajuorganid on väga tundlikud isegi väga väikestele kvalitatiivsetele muutustele, on näha selles, mis juhtub peeglitega (teema, millele eraldivõttes võiks pühendada põhjalikku arutelu ja uurimist). Saab selgeks, et silm [nähes midagi] on mõjutatud [selle poolt, mida ta näeb], nii et see tekitab teatava muutuse. Kui naine menstruatsiooni ajal vaatab juhtumisi väga lihvitud peeglisse, siis muutub selle pind veripunast tooni hägusaks. (Aristoteles, De somniis 459b24jj)

Näites tegutseb peegel omamoodi silmana (osaledes läbipaistvas meediumis) ning saab mõjutatud naise silmadest paistva üldise seisundi poolt. Aristoteles rõhutab, et muutused, mis võivad sellisel viisil toimuda, on sarnased nendele muutustele, kui me vaatame pikalt mingisugust rohelist asja ning siis pöörame pilgu valgele asjale, näib see olevat rohekas. Või sellele, kuidas vein võtab endasse mitte ainult nende asjade mõjud, mida otseselt veini sisse segatakse, vaid ka nende asjade mõjud, mis on veinianumate lähedal (De somniis 461a27). Seega - igasugune ühendus tähendab vastastikust mõju.

\section{Kuri silm ja vorm}

13. sajandi Euroopas kujunes Aristotelese hülomorfismil (mateerial ja vormil) põhinev tajuteooria valdavaks. Keskaegselt mõistetud aristotelismi järgi on tajumine mateeria aktuaalse oleku ehk vormi mittemateriaalne mõjumine nägemine, kuulmine, tundmine on nähtava, heli tekitava, või puudutatava asja vormi (eidos, morphe) vastuvõtmine. Teisisõnu: igasugune kontakt välismaailma ja teiste inimestega toimub vormi kaudu. Keskaja ladina keeles tõlgitakse Aristotelese poolt kasutatud sõna eidos (kuju, vorm) üldjuhul ladinakeelse sõnaga species. (Spruit 1994.) Ladinakeelne sõna species on ka kreeka eidosega sisuliselt seotud, tähistades algselt väljanägemist, kuju või kontuuri, kuid hiljem (nt Cicero, Academica, I.30) aga juba vaimset pilti või ideed. ${ }^{8}$

Nagu ülal näha, võimaldas vormiteooria väga hästi seletada kurja silma toimet, ning küsimus, kas see toimub ekstramissiooniliselt või intromissiooniliselt, ei olegi siinkohal tegelikult kuigi oluline. Et seda ka praktiliselt oli võimalik keskajal kurja silmaga seostada, näeme nt filosoofi ja perspektivisti Roger Baconi juures, kes oma teose Opus maius matemaatikat käsitlevas osas puudutab ka fastsinatsiooni problemaatikat: ${ }^{9}$

Sest Plinius näitab seda Loodusloo seitsmendas raamatus, et paljud inimesed on sellise loomusega, kes nakatavad teisi ja teevad oma kohalolekuga häda, nii pilgu ka kui sõnaga. Kuna sõna luukase loomulike sisemiste liikmete kaudu ja valmib mõtte ja hoolega ja inimene rõõmustab 
selles ning see on ratsionaalse hinge kõige teenistusvalmim instrument ning selle tôttu on see suurema toimega kui ükskõik mis teine asi, mis inimesest tuleb, eriti siis, kui see on lausutud kindla eesmärgiga, suure sooviga ja ägeda kindlusega.

Näitest selgub, et sõna ja pilk toimivad sarnaselt - nad mõlemad kannavad edasi inimese sisemist olemust (hinge), ning kuna nii pilgud kui ka helid on ühendatud hingega ning valmivad inimese sees, saavad need sealt endasse inimese hinge omadusi. Roger Baconi arutlust sõnade ja kõne toimest toetab ka tema kaasaegse Aquino Thomase Aristotelese tõlgendus. Aquino Thomas seletab Aristotelese väidet (De Interpretatione 16b33-17a1), et "sõnad tähistavad asju inimliku kokkuleppe tõttu, mitte aga instrumentaalselt" niimoodi, et inimlikud sõnad ise ei ole naturaalsed nagu loodushääled (kohin, krigin vms), vaid on inimese interpretatiivse võime poolt loodud (Thomas Aquinas, Peri hermeneias, 1.6.8). Lühidalt, inimeste poolt öeldud sõnad on sarnased mistahes käsitööle, mida inimene teeb, ning sõltuvad sealjuures inimese loomusest ja tahtest. Siit lähtudes on võimalik näidata, kuidas inimeses leiduvad kurjad omadused võivad nii pilgu, sõna, lõhna ja ka puudutusega üle kanduda tema pilku, sõnadesse, puudutusse. Sellist idee ülekandumist võib käsitleda sarnaselt nakkuse saamisele. ${ }^{10} \mathrm{Nii}$ on kirjeldanud seda 13. sajandi teoloog ja filosoof Limoges'i Petrus (Friedenthal 2008: 93):

Marutõbisel koeral on ajus mürk. Hammustus temalt mis tahes kehaosasse tekitab hiljem nakkuse ajus või sarnases kehaosas. Nii on tõenäoline, et kiimaline aur, mis tuleb välja naise südamest tema silmadesse, nakatab tema nägemiskiired - kui vaatleme nende [kiirte] ekstramissiooni, mis nakatavad mehe silmad ja hiljem südame, nii nagu see on lähtunud naise südamest.

Samalaadselt on seletanud katku levimist pilgu kaudu 14. sajandi anonüümne meditsiinialase teksti autor (Stearns 2011: 95):

Kuid sellel epideemial on suurem tugevus ning, nagu selgub, surm on kohene, kui õhuline vaim väljub haige silmadest ja tabab lähedal seisva terve inimese silmi, kes haiget vaatab, eriti siis kui nad on agoonias. Sest siis läheb mürgine loomus ühelt liikmelt üle teisele, tappes teise.

Kurja silma toime on keskaegsete teooriate järgi seega olemuslikult sarnane nakkusele ning tema ohtlikkus seisneb eelkõige selles, et see on võimeline mõjuma suuremalt distantsilt kui sõnad, lõhn või puudutus - põhimõtteliselt toimivad need kõik aga ühte moodi. Otsustava tähtsusega on speciese ülekandumine, mis silmade kaudu võib toimuda kõige kiiremini ja kergemini. Üldjuhul on muidugi vajalik, et luuakse silmade kaudu otsekontakt, kuid erandlikel 
juhtumitel on võimalik teist kahjustada ka siis, kui kahjustatav kurja silma omanikule üldse otsa ei vaatagi. Siinjuures viidatakse sageli Pliniuse Loodusloos toodud näitele, mida refereeris eespool Roger Bacon ja millele toetub ka Limogesi Petrus (Friedenthal 2008: 93):

Skü̈̈tias sünnivad teatud naised, keda nimetatakse "bicie”, kellel öeldakse olevat silmades kaks pupilli ja kui nad on väga vihased, pilguga tapavad selle, keda vaatavad.

Võib märgata, et niisuguse kahjustamise juures on väga oluline kahe pupilli olemasolu, sest just pupillis on virtus visiva - nägemisjõud, mis olles kahekordne suudab edastada "bicia" sisemise viha speciest tugevamini kui vaid üks pupill seda suudaks. Selles kontseptsioonis sisaldub implitsiitselt väljutatud speciese enda omadus vahemaa ja takistuse tõttu nõrgemaks muutuda, mis on nähtav ka ülaltoodud katku võimaliku nakkamise näites. Lähedalt toimib kuri silm tugevamini kui kaugelt. Nähtuse selgitamiseks kirjutab Roger Bacon oma Perspectivas (II.2.1) kergest udust, mis lähedalt ei ole märgatav, aga kaugelt vaadates on seda võimalik näha. Rogeri järgi saab ainuke seletus sellisele juhtumisele olla asjaolu, et silmale lähedal on virtus visiva tugev, aga suurema vahemaa tõttu see nõrgeneb ega jõua enam udusest õhust läbi tungida, peegeldudes sealt tagasi silma, mille tõttu me olemegi seda võimelised nägema.

\section{Kokkuvõtvaid märkusi}

Kurja silma toimet saab antiiksete ja keskaegsete nägemisteooriatega seletada loomulikul teel - kuri silm kahjustab küll, aga selline kahjustus on põhjustatud inimese sees leiduvatest halbadest omadustest, mis loomulikul viisil teda ümbritsevat keskkonda mõjutavad. Nii ongi kurja silma kirjeldatud sageli ka seoses nakkushaiguste levikuga. Kuna kõik meeled toimivad põhimõtteliselt sarnasel printsiibil, siis on võimalik väliskeskkonnast võtta vastu kahjulikke mõjutusi kõigi meelte abil - vaid selle tõttu, et nägemine on kõige üllam ning "annab meile kõige rohkem ümbritseva kohta teada ja toob esile erinevusi asjade vahel" (Aristoteles, Metaphysica, I.1.), tõuseb see fastsinatsiooni kontekstis kõige rohkem esile. Sellised hülomorfistliku teooria kontekstis loomulikud seletused taandusid varauusajal, mil tekkisid uued teooriad meeltetajude kohta ja valdavaks sai fastsinatsiooni seletamine üleloomulikul teel (deemonite abil). Lähtuvalt sellest oleks tarvis vaadata ka eesti rahvausundi kurja silma kujutelmade võimalikku seost nägemisteooriatega. Kuna üldiselt on fastsinatsiooni toime väga selges seoses arusaamadega hingest ja tajust, siis oleks võimalik just kurja silma toimemehhanismide kirjeldamise abil heita valgust ka mitmetele teistele olulistele küsimustele. 


\section{Kommentaarid}

1 Artikkel on valminud sihtfinantseeritava teadusteema SF0180040s08 raames.

${ }^{2}$ Kreeka sõnast $\beta \propto \sigma \kappa \alpha i \nu \omega$, mis tähendab eelkõige kurja silmaga kahjustamist, aga sageli ka lihtsalt halva soovimist/põhjustamist. Sõna tuleb üle ladina keelde kujul fascino.

3 Dundesi koostatud artiklikogumikus (The evil eye: a casebook) mainitakse seda mõnel korral möödaminnes, samamoodi ei pööra nägemisteooriatele erilist tähelepanu ka Elworthy ja Seligmann.

4 Ptolemaios tegeles siiski ka nägemise psühholoogilise ja füsioloogilise poolega, aga paraku ei ole see osa tema nägemist puudutavast teosest säilinud.

${ }^{5}$ Olen kasutatud nimevarianti Alhacen, mis on selle araabia teadlase nime (Abū 'Alī al-Hasan ibn al-Hasan ibn al-Haytham) korrektne transkriptsioon. Pikka aega kasutuses olnud variant Alhazen pärineb Friedrich Riesneri 1572. aasta ladinakeelsest väljaandest Opticae thesaurus: Alhazeni Arabis libri septem, nuncprimum editi; Eiusdem liber De Crepusculis et nubium ascensionibus. Üheski keskaegses käsikirjas ei esine tema poolt kasutatud varianti - leidub aga Alhacen, Alacen, Hacen, Achen jts. Vt Smith 2001: xxi, cxxv.

${ }^{6}$ Siin tuleb kindlasti võtta arvesse ka seda, et igasugust maagiat ja nõidust hakati varauusajal sageli seostama deemonite tegevusega ja hereesiaga üldiselt.

7 Siin võib märgata teatavaid sarnasusi Empedoklese arusaamaga, kes räägib, et kõik asjad levitavad lendvat ( $\dot{\alpha} \Pi \circ \rho \rho \circ \alpha i ́)$, mis koosneb kõigist neljast elemendist, ning mis mõjutab kõiki teele ettejäävaid kehasid, nii et isegi kivid mõjutavad üksteist. Lendva abil toimub ainete segunemine, peegeldumine, kasvamine, aga ka meeltetajud jms. (Long 1966: 260-261.)

8 Hanc illi $i \delta \varepsilon ́ \alpha \nu$ appellabant [...] nos recte speciem possumus dicere. Cicero, Academica, I.30. (Lewis \& Short 1879, species)

9 (Rogerus Bacon, Opus maius, IV, 398) Nam Plinius docet septimo Naturalium, quod multi homines sunt talis complexionis, qui alios inficiunt et laedunt ex sua praesentia, et per visum et per verbum. Nam quia verbum ab interioribus membris naturalibus generatur et formatur ex cogitatione et sollicitudine, et delectatur homo in eo, et propriissimum est instrumentum animae rationalis, ideo maximam efficaciam habet inter omnia quae fiunt ab homine, praecipue cum ex intentione certa, desiderio magno, et vehementi confidentia profertu.

${ }^{10}$ Sellel kontseptsioonil on mõningaid sarnasusi 20. sajandil Richard Dawkinsi poolt populariseeritud meemidega, kuid oluliseks erinevuseks on siin see, et kui meemid on kultuurilised, siis eidos (species) on igasuguste omaduste, sh tajumise ja mõtlemise vahendaja (kaasa arvatud suguliselt päranduvad omadused jms).

\section{Kirjandus}

Aristoteles 1990 [1907]. De anima. Hicks, Robert Drew (tlk). Georg Olms Verlag.

Dickie, Matthew W. 1991. Heliodorus and Plutarch on the Evil Eye. Classical Philology 86 (1), lk 17-29.

Dundes, Alan (toim) 1992. The Evil Eye: a Casebook. Madison: University of Wisconsin Press. 
Elworthy, Frederick Thomas 2004. The Evil Eye. The Classic Account of an Ancient Superstition. Mineola, N.Y: Dover Publications.

Friedenthal, Meelis 2008. Tallinna Linnaarhiivi Tractatus moralis de oculo. Dissertationes Theologiae Universitatis Tartuensis 13. Tartu: Tartu Ülikooli Kirjastus.

Gregoric, Pavel 2007. Aristotle on the Common Sense. Oxford: Oxford University Press. Jay, Martin. 1993. Downcast Eyes: The Denigration of Vision in Twentieth-century French Thought. Berkeley: University of California Press.

Lewis, Charlton T. \& Short, Charles 1879. A Latin Dictionary Founded on Andrews' Edition of Freund's Latin Dictionary. Oxford, England: Clarendon Press.

Liddell, Henry 2000. An Intermediate Greek-English Lexicon: Founded Upon the Seventh Edition of Liddell and Scott's Greek-English Lexicon. Oxford \& New York: Clarendon Press; Oxford University Press.

Lindberg, David 1976. Theories of Vision from al-Kindi to Kepler. Chicago: University of Chicago Press.

Long, A. A. 1966. Thinking and Sense-Perception in Empedocles: Mysticism or Materialism? The Classical Quarterly 16 (2). New Series (November 1), lk 256-276.

Lucretius Carus, Titus 2001. On the Nature of Things. Smith, Martin Ferguson (tlk). Indianapolis: Hackett Pub.

Plutarchus 1909. Trench, Richard Chenevix (tlk). The Complete Works of Plutarch: Essays and Miscellanies 3. New York: Crowell.

Rogerus Bacon 1897-1900. Opus maius. Bridges, John Henry (toim). 1-3. London (brepolis.net).

Seligmann, S. 1922. Die Zauberkraft des Auges und das Berufen: ein Kapitel aus der Geschichte des Aberglaubens. Hamburg: L. Friederichsen.

Smith, A. Mark 2001. Alhacen's theory of visual perception: a critical edition, with English translation and commentary, of the first three books of Alhacen's De aspectibus, the medieval Latin version of Ibn al-Haytham's Kitab al-Manazir 1. Philadelphia: American Philosophical Society.

Sprague, Rosamond Kent 1985. Aristotle on Red Mirrors ("On Dreams" II 459b24460a23). Phronesis 30 (3) (January 1), lk 323-325.

Spruit, Leen 1994. Species Intelligibilis. Classical Roots and Medieval Discussions 1. Brill's Studies in Intellectual History 48. Leiden: Brill.

Stearns, Justin K. 2011. Infectious Ideas: Contagion in Premodern Islamic and Christian Thought in the Western Mediterranean. Baltimore: JHU Press.

Story, William W. 2003. Castle St. Angelo and the Evil Eye. Kessinger Publishing.

Taylor, C. C. W. 2010. The Atomists: Leucippus and Democritus: Fragments. Toronto: University of Toronto Press.

Thomas Aquinas 1955. S. Thomae Aquinatis in Aristotelis libros peri hermeneias et posteriorum analyticorum expositio. Spiazzi, Raimondo M. (toim). Marietti. 


\title{
Summary
}

\section{The Evil Eye: Descriptions of Operation According to Ancient and Medieval Theories of Perception}

\author{
Meelis Friedenthal
}

Key words: evil eye, extramission, intromission, theories of vision

The mechanism of evil eye can be explained according to the ancient and medieval theories of perception in natural terms. The damaging qualities of evil eye are caused by the bad qualities present in the person and are naturally affected onto his environment. Since all the senses operate essentially with the same principle, this happens not only through vision, but also through sounds (words), touch and smell. Accordingly the evil eye is often described in connection with infectious diseases (miasma theory). Only because the vision is the most noble, and "most of all the senses, makes us know and brings to light many differences between things" (Aristotle, Metaphysica, I.1.) are eye and vision highlighted in the context of fascination. All ancient theories of perception allow such affecting from long distance. This applies not only to the extramission (emission) theories of vision (what are usually mentioned in connection with the phenomenon of evil eye) but also some intromission theories of vision are able to account for the effects of evil eye. In the present article examples from Plutarchos, Aristotle, Roger Bacon, Peter of Limoges and others are employed to illustrate the principles. A central concept that emerges is the Aristotelian principle of eidos (in medieval times usually translated as species) what transmits qualities incorporeally to recipients. Every act of perception is in some way connected with the soul. Thus it is generally necessary for evil eye to operate, that direct contact between eyes is established, but in some cases it is also possible to damage the other even if the affected person does not herself have direct contact with the evil eye. This can happen when the evil qualities inside the fascinators soul are transmitted by other means (sound, smell, etc) or when the virtus visiva inside the eyes of the fascinator is extremely strong (as with the case of Triballi and the Illyrii described by Pliny). Another possibility is the extreme sensitivity (malleable soul) of the victim. As children and women are more sensitive than men usually evil eye is more dangerous to them. How qualities inside human soul are able to affect inanimate matter is illustrated with the example of red mirrors (Aristotle, De somniis 459b24ff). Such general understanding of fascination was in use till Early Modern times, when the phenomenon of evil eye become to be explained not any more by natural but supernatural means (demons). 